Магда Г. Миликић

Институт за српску културу Лепосавић ${ }^{1}$
821.111(73).09-31Апдајк Џ.

Originalni naučni rad

Primljen: 12.04.2020

Prihvaćen: 19.08.2020

\title{
ДА ЛИ ЈЕ АМЕРИКА КРМАЧА КОЈА ПРОЖДИРЕ СВОЈ ОКОТ: АПДАЈКОВ ТЕРОРИСТА КАО ОБРАЗОВНИ РОМАН
}

Теза овог рада је да се двадесет други роман Џона Апдајка, Терориста (2006), може посматрати као образовни роман (Bildungsroman). Истраживање се заснива на теоријским увидима о овом романескном облику које нуде најпре Хегел, Лукач и Бахтин, али се консултују и савремени теоретичари овога појма. Једна од основних одлика образовног романа је промена кроз коју пролази млади човек, а која има пресудну улогу у формирању његове личности. Та промена настаје на основу дијалектичког односа између сопства и околине. Међу проучаваоцима доминира становиште да се сукоб у оквиру образовног романа успешно решава, тако што долази до компромиса између сопства и света. На основу анализе Терористе Џона Апдајка проверићемо да ли се ово дело - и под којим условима - може сврстати у традицију образовног романа. При томе ћемо, између осталог, Апдајков роман смештати и у компаративни контекст, тако што ћемо га у одређеним аспектима поредити са Џојсовим Портетом уметника у младости, а спорадично и са Мановим Чаробним брегом. Коначно, један од (посредних) циљева рада је и да укаже на поетичке тенденције савременог образовног романа.

Кључне речи: Џон Апдајк, Терориста, образовни роман, исламски фундаментализам, Ахмед Ашмави Малој, развој, епифанија

\author{
„[...] понекад сам усамљен, \\ а и плашим се, \\ држим те на столу, Господе." \\ (Бранимир Џони Штулић, 3Н)
}

\footnotetext{
*_magdamilikic95@gmail.com

1 Овај рад је настао у оквиру ангажовања Магде Миликић као стипендисте Министарства просвете, науке и технолошког развоја у раду Института за српску културу у Приштини, са привременим седиштем у Лепосавићу.
} 
Џон Апдајк (1932-2009) амерички је аутор који је обележио не само америчку већ и светску књижевност (пре свега) двадесетог века. Написао је велики број романа, збирки прича, песама и есеја. Иако је његов опус разноврстан, сматра се првенствено романописцем (Дојчиновић Нешић 2007: 5). Добитник је награде „National Book Award”, за роман Кентаур (1963), као и две Пулицерове награде, за романе из тетралогије о Зеки Ангстрому, Зека је богат (1981) и Зека на починку (1990).

Његова прва прича, „Пријатељи из Филаделфије” објављена је 1954. године, у часопису Њујоркер; она је у тематско-мотивском аспекту егземпларна за перо писца из Пенсилваније, те се може посматрати као својеврсна епрувета из које је настало потоње Апдајково стваралаштво. Теме којим ће се бавити овај аутор, а које су заступљене већ у његовој првој причи су: савремени живот у Америци, нарочито у оквиру средње класе ${ }^{2}$ живот у оквиру породице; мушко-женски односи; сексуалност; култура медија: примера ради, типична апдајковска сцена приказује пасивног, летаргичног (анти)јунака који сатима гледа телевизију. Прича „Пријатељи из Филаделфије” не бави се питањем Бога, која је такође једна од опсесивних тема Џона Апдајка ${ }^{3}$, а о којој - када је реч о ранијим Апдајковим делима - можемо читати, рецимо, у причи „Голубије перје”(1959). Прича „Ас у рупи” (настала 1953, објављена 1955) представља заметак романа Бежи, Зеко, бежи (1960), односно тетралогије о Харолду Харију Ангстрому Зеки (Дојчиновић 2018: 368); у овој причи уводе се типично апдајковски мотиви: ескапизам; Бог; изванредно, несвакидашње, које је насупрот осредњем и свакодневном; сексуалност; комплекс мајка - син и др.

Предмет нашег бављења је двадесет други роман Џона Апдајка, Терориста (2006), чија је радња смештена у Америку, у 2003. годину. У његовом средишту су терористички напади извршени 11.

2 При томе се Апдајк често бави темом конзумеризма, који се спорадично односи и на књижевне феномене. Например,средњошколку Телму, једну од актерки приче „Пријатељи из Филаделфије”, затичемо какочита роман увијен у целофан (Апдајк 2003: 36). Овим детаљем се указује и на доминацију бестселер литературе над књижевношћу која има већу естетску вредност.

3 У овој причи тематизује се пак (не)постојање правде: имплицирано је питање има ли правде на свету ако онај ко није завршио факултет вози бољи ауто од оног ко има високо образовање (Апдајк 2003: 37). Правда се овде, сходно конзумеристичком духу (епохе), доводи у вези искључиво са материјалним стварима и тако се иронизује. 
септембра 2001. године, премда се у самом тексту тек овлашно помињу. У студији Самоубилачки тероризам: како се постаје „мученик” Виолете Матовић читамо да су се 11. септембра 2001. четири авиона, који су били на линијама комерцијалних летова, обрушили на зграде Светског трговинског центра на Менхетну у Њујорку и на Пентагон у Вашингтону. Два су погодила тзв. Куле близнакиње, један седиште министарства одбране Сједињених Америчких Држава, а један је оборен на подручју Пенсилваније, и то, како се претпоставља, услед борбе између путника и отмичара авиона. Према Матовићевој, погинуло је 2.792 људи. Сматра се да је напад организовала и извела „Ал Каида", међународни савез исламских терористичких организација, која уједињује, финансира, те на различите начине помаже и координише деловање фундаменталиста широм света (Матовић 2006: 46). Жан Бодријар у есеју „Дух тероризма” пише да смо „,s napadima na Njujork i Svetski trgovinski centar imali [...] posla s apsolutnim događajem, 'majkom' svih događanjâ, s čistim događajem koji u sebi koncentriše sve događaje koji su nam se ikada desili” (Бодријар 2007: 7). Француски филозоф сматра да се ови напади у симболичком симислу представљају иморалан одговор на мондијализацију, која је и сама иморална (Бодријар 2007: 12). Апдајк се, дакле, и у овом роману усмерава на актуелну тему, што је велики изазов за сваког стваралоца, између осталог, зато што писац нема временску и психолошку дистанцу у односу на феномене које литерарно обрађује.

Средишња тема Терористе је потрага за идентитетом у мултиетничкој средини и мултиетничкој породици (Крибернег 2011: 218). Главни јунак је осамнаестогодишњак Ахмед Ашмави Малој, син Американке ирско-католичког порекла, и Египћана који је разменом студената дошао у Америку, а потом брзо отишао из ње, када је дечак имао три године. Ахмед је озбиљан, фокусиран, дисциплинован, интелектуалан, али и усамљен младић; гаји отпор према америчком духу конзумеризма, а пре свега према америчкој доминантно секуларној, односно - према Ахмедовом уверењу - само номинално религиозној популацији. Два пута недељно одлази у џамију, где учи арапски, чита и проучава Куран; имам који га подучава сматра да Ахмед треба да постане возач камиона, бомбаш самоубица, док школски саветник за професионалну оријентацију, не тако побожан, депресиван Јевреј, Џек Леви, у њему види будућег студента. 
Магда Г. Миликић

У наставку рада настојаћемо да проверимо да ли се Терориста и под којим условима може уклопити у традицију образовног романа.

\section{„We Don't Need No Education": Апдајков Терориста као образовни роман}

У трећој књизи Хегелове Естетике налазе се схватања немачког идеалисте о роману као књижевном облику. Аутор Феноменологије духа најпре има у виду ону поетичку линију коју представља Гете са својим романима, а која је обележила немачку књижевност друге половине осамнаестог и прве половине деветнаестог века. Наиме, Хегел у овом одељку о „роману, тој грађанској епопеји”, која приказује „тотални свет”(Хегел 1961: 476), нуди, између осталог, својеврсну дефиницију Bildungsromana ${ }^{4}$, премда се његово одређење не односи само на дела у овом књижевном облику. Немачки идеалиста говори о сукобу између „прозе прилика” и „поезије срца”, који можемо уочити и у романима о Вилхелму Мајстеру; Хегел образовни роман види пре свега као наратив о сазревању:

[...] Због тога један од најобичнијих и за романе најзгоднијих сукоба јесте сукоб између поезије срца и прозе прилика која стоји насупрот, као и случајност спољашњих околности: један раздор који се решава или трагично или комично, или своје решење налази у томе што, с једне стране, они карактери који су се најпре противили постојећем поретку у свету успевају да увиде и признају оно што је у њему пра̂во и супстанцијално, па мирећи се са приликама у њему ступају у њега као његови активни чланови, а с друге стране опет скидају са онога што производе и стварају прозаични облик и тиме наместо затечене прозе стављају једну стварност која је пријатељска и сродна са лепотом и уметношћу.(Хегел 1961: 476)

4 Термин „Bildungsroman” сковао је естетичар Карл фон Моргенштерн 1810. године, премда ће у ширу употребу у науци о књижевности ући са Дилтејем (Махони 1991: 69).Први део кованице потиче од немачког глагола „bildensich”, који значи „образовати се”, „изградити се”. 
Важно је нагласити да је образовни роман специфичност немачке књижевности (Сејмонс 1991: 28), и то оног књижевноисторијског тренутка када је у овој култури била доминантна идеалистичка филозофска мисао. Након тога се не може говорити о класичном образовном роману. На сличан начин овај романескни облик види и Ђерђ Лукач, најпре хегелијански, а касније доминантно марксистички оријентисан филозоф и књижевни критичар. У својој студији о Годинама учења Вилхелма Мајстера, он говори о измирењу проблематичне индивидуе, вођену „doživljenim idealom”,са „konkretnom, društvenom stvarnošću" (Лукач 1968: 99), а као основни проблем образовног романа издваја трагање за смислом живота у свету који се доживљава као стран и непријатељски, при чему је пут проблематичног јунака усмерен ка срећном и складном разрешењу (Лукач 1968: 101).

Bildungsroman често тематизује образовање индивидуе у оквиру институције и тако у великој мери третира педагошка питања. Такав роман био би, рецимо, Џојсов Портрет уметника у младости (1916), који се жанровски одређује као роман о уметнику (Künstlerroman), а који је једна од метаморфоза образовног романа 5 . С друге стране, спиксак образовних романа у европској књижевности који нуди Бахтин показује нам да овај проучавалац Bildungsroman схвата као обухватнију књижевну форму која се не бави само педагошким проблемима него приказује и утицај друштва на формирање личности, када је блиска друштвеном, тј. реалистичком роману балзаковског типа (Бахтин 2013). Слично Бахтину, савремени италијански теоретичар и историчар књижевности Франко Морети ову књижевну форму види као синтезу романа о развоју и романа о васпитању (Морети 2000). Јирген Јакобс и Маркус Краузе, такође савремени тумачи овога појма,под образовним романом подразумевају она дела „u с̌ijem se središtu nalazi životna priča mladog protagoniste, koja će, preko niza zabluda i razočaranja, dovesti do pomirenja sa svetom” (Јакобс, Краузе 2000: 514).

\footnotetext{
5 У мотоу Џојсовог романа првенца стоји управо цитат из Овидијевих $\mathrm{Me}$ таморфоза: „I usmeri svoj um ka nepoznatim veštinama” (Џојс 2015: 5); синтагмом „непознате вештине” упућује се на промену коју главни јунак, Стивен Дедалус, у тренуцима епифаније доживљава; усмеравање ка „непознатим вештинама” у контексту овог романа може имати и метапоетичко значење: односи се на преосмишљавање традиције причања прича̂.
} 
Протагониста Терористе, Ахмед Ашмави Малој, матурант је „Централне гимназије” у Њу Проспекту, у држави Њу Џерзи. У призору којим се дело отвара затичемо га у школском амбијенту како размишља о својој околини: „Đavoli, misli Ahmed. Ovi đavoli hoće da mi uzmu mog Boga. Ceo bogovetni dan se devojke u Centralnoj gimnaziji uvijaju i podrugljivo smeju pokazujući svoja meka tela i zavodljivu kosu" (Апдајк 2006: 9). Већ на основу првих неколико реченица можемо увидети да јунак има изразито негативан и негаторски однос према гимназији у којој се образује: „Централна гимназија” и читаво њено окружење за њега су демонски, нечист простор. Како је већ приметила Драгана Машовић, Ахмед се плаши да ће га окружење разбожити и натурализовати на амерички начин живота (Машовић 2018: 143). Школска средина је у Терористи приказана као простор који настоји да дестабилизује јунаков верски живот, стога што је простор лицемерног облика егзистенције: „Nastavnici, neubedljivihrišćani i neverni Jevreji, pretvaraju se da predaju o vrlini i opravdanom uzdržavanju, ali njihove prepredene oči i šuplji glasovi pokazuju nedostatak verovanja kod njih. Njih grad NjuProspekti država Nju Džerzi plaćaju da tako govore" (Апдајк 2006: 9).

У делусе первертује просветитељски модел класичног образовног романа: Ахмед нема поверења у школу као институцију. При томе је важно истаћи да, иако је епоха просветитељства вековима за нама, савремена цивилизација утемељена је на њеним тековинама. Док су просветитељски мислиоци заговарали критички однос према религији, Ахмедов поглед на свет заснива се на непримишљено прихваћеној догми; уз то, његова религиозност није аутентична, већ у великој мери извитоперена, због тога што се не заснива на љубави, разумевању и емпатији, већ на анимозитету према свету који га окружује.

На основу претходних навода увиђамо да је нарацији заступљена унутрашња фокализација, посредством које се (и) у приповедним сегментима дела оглашава са̂м јунак, који, видимо, има негативан став према својој околини. Суптилно и често неприметно смењивање свезнајуће наративне инстанце и најчешће Ахмедове перспективе, свакако, уноси дозу двосмислености у семантички слој Терористе. Како не можемо са сигурношћу тврдити шта нам казује приповедач, а шта јунак, тако и (традиционално схваћена) по(р)ука дела није транспарентна и једнозначна, већ је скривена у различитим слојевима Терористе. 
У претходном наводу јунак исказује негативан став према граду и савезној држави у којој живи; даље у роману примећујемо да је он антагонистички настројен према (конзумеристичком) духу Сједињених Америчких Држава уопште, што можемо прочитати у следећем Ахмедовим речима, упућеним Џолирин, девојци из разреда према којој гаји извесне симпатије, али којој замера слободу у држању и опхођењу:

„Ima ih mnogo kao što sam ja”, kaže joj on, i kruto i nežno, napola joj prebacujući. „Neki su” - ne želi da kaže „crni”, jer iako je reč politički ispravna ne zvuči ljubazno - „oni koje ti zoveš svojom braćom. Džamija i njeni učitelji pružaju im ono što hrišćanske Sjedinjene Države preziru - poštovanje i izazov da se nešto od njih traži. Traži se štedljivost. Traži se uzdržanost. Sve što Amerika hoće od svojih građana, tvoj predsednik je rekao, jeste da kupujemo - da trošimo novac koji nemamo i da tako guramo privredu napred za njegov račun i račun drugih bogatih ljudi”.(Апдајк 2006: 79-80)

Ако обратимо пажњу на који начин јунак у овом цитату поима свој етничко-национални идентитет, уочићемо амбиваленцију: сугерише се да Ахмед себе види и као неамериканца и као Американца. Наиме, он употребљава присвојну заменицу другог лица, те и глаголски облик у првом лицу множине: „,...] tvoj predsednik je rekao [...] da trošimo novac koji nemamo [...] (истакла М. М.)”. Овакви искази, који показују да јунак и припада и не припада заједници у којој живи, нису ретки у роману.

Коначно, јунаков анимозитет тиче се Западног света као таквог, што протагониста са̂м експлицира док са Џолирин разговара о чедности, која према исламским уверењима у оностраности бива награђена девицама: „Moj učitelj u džamiji misli da su crnooke device simbol blagoslova koji čovek ne može zamisliti bez konkretnih slika. Tipično je za Zapad opsednut seksom to što se uhvatio za tu sliku i zbog toga se podsmeva islamu" (Апдајк 2006: 79; подвукла М. М.). Ахмед Западној цивилизацији замера то што је иноверна, а пре свега морално декадентна. Тако „прозу прилика̂” у делу представља јунаково „неверничко” окружење.

У делу можемо пронаћи неколико мотивацијских линија које се тичу Ахмедовог анимозитета према непосредном окружењу, али и це- 
локупном Западном свету. Једним делом је мотивисан тиме што у средини у којој јунак живи постоји отпор према - њему као муслиману. Момак Џолирин, Тиленол Џонс, дозива га подругљиво, речима „Неј, Arapine” (Апдајк 2006: 21), понижава га и физички злоставља: „[...] ti si tako glup da nikoga nije briga za tebe, Arapine [...] Uvrnutipederašu. Peško [...] Crnemuslimaneja ne vređam, ali ti nisi crn, ti si samo jadan bezveznjak. Ti nisi Arapin, ti si posranac” (Апдајк 2006: 22); затим „udara Ahmeda pesnicom u stomak, što mu izbacuje sav vazduh" (Апдајк 2006: 22). Према схватањима социолога Антонија Смита која елаборира у студији Национални идентитет, западни модел нације је „грађански”: заснива се на просторном, територијалном схватању (Смит 2010: 23), те, сходно томе, индивидуа може изабрати свој национални идентитет (Смит 2010: 26). Насупрот западном стоји „незападно”, „етничко” схватање нације, које се темељи на припадању истој „лози”; оно наглашава заједницу рођења и родне културе, због чега је непроменљиво (Смит 2010: 26). Примећујемо да се јунак поима као Другост, иако то - ако имамо у виду Смитово одређење западног схватања нације - не бисмо очекивали. Стога се чини да писац Терористе сугерише да америчко поимање идентитета није у потпуности грађанско, територијално, чак ни у средини каква је Њу Џерзи, коју Апдајк приказује као мултиетничку. Ахмед је, видимо, изложен својеврсном вршњачком насиљу због тога што је друге вере, што не припада „у потпуности" Сједињеним Америчким Државама. Његово порекло је врло комплексно: уједно и ирско, и египатско, и америчко. Даље, подсећамо да је радња романа смештена у 2003. годину, две године након терористичких напада, када је, и према Апдајковом роману, у овој земљи у великој мери заступљена исламофобија, због чега се јунак може осећати у различитом смислу угрожено. Затим, у делу је наговештена и Ахмедова фрустрација због одмазде коју је Америка покренула на Блиском истоку, на шта би могле указивати његове следеће речи, упућене Џеку Левију, школском саветнику, у којима Американце поистовећује са хришћанима: „Pogledajte kako su hrišćani izvršili genocid nad starosedeocima Amerike i potkopali Aziju i Afriku, a sada su se ustremili na islam (истакла M. M.), a svime u VašingtonurukovodeJevreji da bi ostali u Palestini” (Апдајк 2006: 45). Коначно, чини се да је протагониста негаторски оријентисан према свом окружењу и услед оскудице у којој живи: „Ahmedu je izgledalo da se njegova majka razmeće 
svojim siromaštvom, svakodnevnim neuspehom da se uklopi u srednju klasu" (Апдајк 2006: 152). Он у једном моменту исказује огорченост услед оваквог социо-економског статуса. Наиме, у расправи са школским саветником, који тврди да Ахмед треба да упише факултет, а не да вози камион, у наративном проседеу у ком се, по свој прилици, оглашава са̂ протагониста романа, читамо: „Oni umiru od želje da on završi školu i da ga se reše. I kad završi gde bi? U imperijalistički privredni sistem koji je napravljen u korist bogatih hrišćana (истакла М. М.)" (Апдајк 2006: 87-88).

За Ахмедово формирање је од „Централне гимназије” значајнија једна друга институција. Већ на почетку романа сазнајемо да јунак има учитеља, шеиха Рашида, који је имам у џамији, код ког од своје једанаесте одлази два пута недељно да тумачи Куран. Обратимо пажњу на први њихов разговор који је приказан у делу:

Šeih Rašid recituje sa divnim izgovorom stočetvrtu suru, koja se odnosi na hutamu, razbuktalu vatru:

A ko će te naučiti šta je razbuktala vatra?

To je vatra koju je potpalio Alah,

Koja će do srca prokletih dopirati.

Ona će iznad njih biti zatvorena,

Plamenim stubovima zasvođena.

Kada Ahmed nastoji da izvuče slike na arapskom u Kuranu - plamene stubove, fi 'amadin mumaddada, i svod visoko iznad srca onih koji su se šćućurili u strahu i naprežu se da vide kroz izmaglicu što se iznad njih uzdiže od usijanog žara, nāru 'l-lāhi 'l-mūqada - neki nagoveštaj da Samilosni popušta u izvesnom momentu i traži da se hutama zaustavi, imam spušta pogled, očiju koje su neočekivano bledosive, mlečne i neuhvatljive kao kod kafirske žene, i kaže da su ovi vizionarski opisi Proroka figurativni. Oni zaista govore o jakoj patnji odvajanja od Boga i ognju našeg kajanja zbog grehova koje smo počinili protiv Njegovih zapovesti. Međutim, Ahmedu se ne sviđa glas šeiha Rašida kada on to kaže. Podseća ga na neubedljive glasove njegovih nastavnika u Centralnoj gimnaziji. On u tome čuje tih glas satane, jedan glas koji poriče ono što drugi tvrdi. Prorok je mislio na fizičku vatru kada je propovedao o vaatri koja ne prašta; Muhamed nije mogao prečesto da objavljuje činjenicu o večitoj vatri. 
Šeih Rašid nije mnogo stariji od Ahmeda - deset, možda dvadeset godina. On ima malo bora po beloj koži lica. Snebivljiv je iako precizan u svojim kretnjama. U godinama za koliko je stariji, svet ga je načinio slabijim. Kada mrmljanje đavola koji ga iznutra nagrizaju oboji imamom glas, Ahmed oseća želju da ustane i da ga smrvi isto tako kao što je Bog spržio onog jadnog crva u središtu spirale. Vera učenika prevazilazi veru nastavnika; šeih Rašid plaši se da jaše na belom krilatom đogatu islama, plaši ga njegov juriš. On nastoji da ublaži reči Prorokove, da ih pomeša sa ljudskim razumom, ali im nije bila namena da se mešaju: one prodiru u ljudsku mekoću kao mač. (Апдајк 2006: 12-13)

Разбуктала ватра и пламени стубови, о којим се говори у наведеном сегменту Курана, могу бити метафоре за унутрашњу, индивидуалну борбу са помислима и искушењима, али се могу односити и на физички обрачун са неисламским светом. Шеих Рашид за разговоpe са Ахмедом, заправо, начелно бира овакве делове Курана, који се могу тумачити и са аспекта исламског фундаментализма. Након читања потенцијално милитантног одељка, ,imam spušta pogled (истакла M. M.), očiju koje su neočekivano bledosive, mlečne i neuhvatljive kao kod kafirske žene, i kaže da su ovi vizionarski opisi Proroka figurativni”. Ахмеду се „ne sviđa” глас шеиха који (барем номинално) метафорички тумачи одељак из свете књиге; јунак буквално разумева ватру и пламене стубове из Курана: „Podseća ga na neubedljive glasove njegovih nastavnika u Centralnoj gimnaziji. On u tome čuje tih glas satane, jedan glas koji poriče ono što drugi tvrdi(подвлачења М. M.). Prorok je mislio na fizičku vatru kada je propovedao o vatri koja ne prašta". Већ овде примећујемо да у овом јунаку има нечега од парадоксалне привлачности негативног јунака, о којој говори Никола Милошевић.

Лукач говори о „traganju za smislom u svetu koji se doživljava kao stran i neprijateljski” у оквиру образовног романа(Лукач 1968: 103). Тај смисао се овде иронично назире у идеји о физичкој борби са иноверницима. Мађарски теоретичар истиче да Вилхелм Мајстер нема погрешне тежње, већ се његов проблем огледа ,управо у томе што је уопште пожелео да своју душевност оствари у свету" (Лукач 1968: 103). За разлику од осамнаестовековног јунака класичног образовног романа, протагониста Терористе, који живи у двадесет првом веку, има, дакле, погрешне тежње. „Поезијасрца” се у Терористи у вели- 
ДА ЛИ ЈЕ АМЕРИКА КРМАЧА КОЈА ПРОЖДИРЕ СВОЈ ОКОТ ...

кој мери заснива на милитантном односу према Другости, а Другост je, заправо, сведена на елемент религијског: док јунак првобитног Bildungsroman-a стреми што обухватнијем и далекосежнијем знању, главни лик је код Апдајка фокусиран искључиво на политичко-делатну функцију ислама. Овакво становиште, по ком је исламска религиозност начелно прагматична, јесте стереотипно.

У роману се не казује на који начин је јунак постао религиозан и зашто се одлучио за религију свог одсутног оца ристе затичемо га као ревносног и посвећеног муслимана, истина, са клицом екстремизма. За њега је ислам „svojevoljno izabran identitet” (Апдајк 2006: 191). Џек Леви ће приликом једне од посета јунакове мајке, изнети једно од могућих објашњења: „Toga imamnogo u [...] crnimporodicama, decaidealizujuocakojinijetu i usmeravajusvusvojuljutnj unajadnustarumamukoju se ubi od posla da bi imalikrovnadglavom" (Апдајк 2006: 97). Ахмед, свакако, „проналазак” ислама види као неку врсту поновног сусрета са оцем: „On je mislio da bi u ovoj veri mogao da nađe trag lepog oca koji se povukao u času kada je njegovo sećanje počinjalo" (Апдајк 2006: 108).

Када износи становиште о одређеној теми, јунак се врло често позива на свог учитеља, шеиха Рашида, који за њега представља највећи ауторитет. Објашњавајући Џеку Левију због чега не намерава да упише факултет, говори како га је у том смислу саветовао имам: „Rekao je da me usmeravanje na koledž izlaže štetnim uticajima - loša filozofija i loša književnost. Zapadna kultura je neznabožačka” (Апдајк 2006: 45); „Moj učitelj smatra da bi trebalo da vozim kamion” (Апдајк 2006: 48). У томе што се ослања на туђа уверења може се увидети да је Ахмед несигурна, неформирана личност, која још увек није изградила сопствени интегритет. Стога јунаку ова схватања нису иманентна, већ их је (само) донекле интериоризовао.

Он се, видимо, „plašio” „da bi više obrazovanja moglo da oslabi njegovu veru" (Apdajk 2006: 231). Мотив опасног знања могло би се довести у везу са библијским текстом. Наиме, Исус Христос у Беседи на гори - о којој се говори у Јеванђељу по Матеји - између осталог, каже да су „блажени сиромашни духом, јер је њихово Царство небеско" (Библија 2018: 1202). Једно од бројних тумачења овог прилично

6 О психолошким импликацијама одсуства оца у Терористии в. Алгамди 2015: 4-6. 
комплексног стиха указује на шкодљивост световног, тј. изванрелигијског знања; Ахмедов страх да би знање могло да угрози његову религиозност може се упоредити и са одељком из Постања где се говори о првом греху, односно о дрвету познања добра и зла. Уз то, као мото у Терористи стоји цитат из Старог завета, из приче о Јони. Стога наслућујемо да приповедач добро познаје и хришћанску и муслиманску свету књигу, у чему би се могла крити његова „идеологија”.

Инсекти (бубе и бубашвабе) јесу својеврсна Ахмедова фасцинација; они су лајтмотив дела и представљају алегорију за иновернике: „Ahmed imaosamnaestgodina. Početak je aprila. Opet se zelenilo uvlači, seme po seme, u sumorne pukotine u zemlju grada. On gleda nadole sa svoje nove visine i misli da bi on bio Bog insektima koji se ne vide u travi, da imaju svest kao što je njegova. Protekle godine je porastao za sedam i po centimetara i dostigao metar i osamdeset tri" (Апдајк 2006: 10). Јунак себе види не само као супериорног у односу на инсекте већ као Бога над њима, и то због своје физичке надмоћности, која се може схватити и симболички. Релацију Бог - Ахмед јунак, дакле, пројектује на однос Ахмед - инсекти. У наредном сегменту пак примећујемо да протагониста гаји емпатију према овим створењима, премда се не усуђује да искаже своје становиште:

„Da li imaš sažaljenja za bubašvabe koje ispuzavaju ispod poda i česme? Muve koje zuje oko hrane na stolu, hodaju po njoj prljavim nogama koje su upravo igrale na izmetu i strvinama - da li njih sažaljevaš?

Ahmed ih je, istinu govoreći, sažaljevao, jer je bio fasciniran ogromnom populacijom insekata koji su gmizali pored nogu bogolikih ljudi ali, znajući da bi bilo kakva kvalifikacija ili znaci dalje rasprave razljutili učitelja, odgovorio je: „Ne.”

„Ne”, šeih Rašid se sa zadovoljstvom saglasio, dok je nežnom rukom lagano povlačio bradu. ,Ti želiš da ih uništiš. Oni te sekiraju zbog nečistoće. Oni bi preuzeli tvoj sto, tvoju kuhinju; smestili bi se u samu tvoju hranu dok je stavljaš u usta ako ih ne uništiš. Oni nemaju osećanja. Oni su ispoljavanje satane i Bog će ih uništiti bez milosti kada dođe sudnji dan. (Апдајк 2008: 84)

Предраг Мићић у студији Самоубилачки тероризам говори и о разлозима зашто самоубице најчешће постају они који имају између 
18 и 27 година. На овом дугачком списку налазе се и фрустрираност, несналажење, лоша финансијска ситуација, лоши услови живота, недостатак самопоуздања и губитак блиске особе (Мићић 2006: 189), што су одлике и околности који се могу повезати и са Ахмедом. При томе - као што смо већ сугерисали - Апдајков јунак нема нарочито развијен однос са мајком, што га, чини се, чини додатно усамљеним и незадовољним: „Mi nikada nismo dobro komunicirali. Između nas je bilo odsustvo mog oca, a onda moja vera, koju sam prihvatio pre nego što sam ušao u tinejdžerske godine. Ona je jedna topla žena i nesumnjivo brine za svoje pacijente u bolnici, ali mislim da za majčinstvo ima talenta koliko i mačka" (Апдајк 2006: 227). Своју мајку, Терезу, видео је као одвећ распусну и грешну жену: „Ahmed je svoju majku posmatrao kao grešku koju je njegov otac napravio, ali on nikada neće" (Апдајк 2006: 184). Лице које брзо поцрвени јунак каже да је „nažalost” наследио од мајке (Апдајк 2006: 84). Поред шеиха Рашида, дакле, не постоји друга особа са којом је Ахмед близак. Између осталог, због тога се јунак не усуђује да противуречи његовим схватањима.

Џолирин пева у црквеном хору, па позива Ахмеда на литургију, да чује њено солистичко певање. Иако је „šokiran” овим позивом (Апдајк 2006: 16), пристаје, јер је, како са̂м каже, „do izvesne mere” „korisno upoznati neprijatelja” (Апдајк 2006: 76). Одлази на католичку службу, коју ће углавном пратити са ниподаштавањем, гнушањем и отпором: служба није ни почела, а он већ „mrzi Džolirin što ga je namamila u takvu škakljivu zamku" (Apdajk 2006: 59). Након читања библијске приче, свештеник држи беседу; говори људима да не буду попут неверника̂, „,sinovaIzrailjevih” из старозаветне приче о Мојсију и земљи Хананеја:

„Recite mi šta vam je potrebno”.

„Vera”, slabašno izgovara nekoliko glasova, nesigurno.

„Da čujem to opet glasnije. Šta nam je svima potrebno?”

„Vera”, čuje se jedinstven odgovor. Čak i Ahmed izgovara tu reč, ali tako da ga niko ne može čuti osim male devojčice pored njega. (Апдајк 2006: 68)

На тренутак и Ахмед бива „увучен” у ток службе: изговара реч „вера” (у оригиналу „faith” (Апдајк 2007: 51). Он - истина, само на тренутак - освешћује да је појам вере шири од појма религије, и да управо вера представља спону између њега и људиि који га у том тре- 
нутку окружују, а које до тада, али и после тога, назива неверницима. Ахмед верује у Алаха, хришћани у Исуса Христоса, али их све повезује вера у трансцеденцију, имплицитна је „порука”. Овај сегмент је донекле конзистентан са одељком где јунак са сажаљењем посматра бубе и показује своју фасцинацију инсектима. И један и други део показују да је Ахмеду инхерентна емпатија према свету који га окружује, али је она прикривена слојевима индоктринације шеиха Рашида. Тако увиђамо да се „поезија срца” у Терористи не заснива искључиво на милитантном односу према Другости, премда је такав став јунака доминантан.

Свештеник у беседи помиње бројне библијске личности, старозаветне и новозаветне, попут праоца Аврама, пророка̂ Јоне и Данила, Исуса Христоса:

Avram, Noje: ova imena nisu potpuno nepoznata Ahmedu. Prorok je u trećoj suri potvrdio: Mi verujemo u Alaha i u ono što se objavljuje nama i u ono što je objavljeno Avramu i Išmaelu, i Isaku i Jakovu, i plemenima, kao i ono što je dato Mojsiju i Hristu i Prorocima od njihovog Gospoda. Mi nikakvu razliku među njima ne pravimo. Ovi ljudi oko njega su na svoj način sledbenici knjige. Zašto vi ne verujete u znake Boga? (Апдајк 2006: 69)

Јунак се тада присећа одељка из Курана у коме Мухамед говори како се религија коју он проповеда заснива на вери у Алаха, али и, како каже, у „ono što se objavljuje nama i ono što je objavljeno Avramu i Išmaelu, i Isaku i Jakovu, i plemenima, kao i ono što je dato Mojsiju i Hristu i Prorocima od njhovog Gospoda". Мухамед подсећа на заједничку основу аврамских религија и тако, истина, на посредан начин, позива на религијску толеранцију. У литератури о Терористи је, заправо, већ речено да овај роман позива на толеранцију, пријатељство и религијски релативизам (Крибернег 2011: 226). Ахмед пак не размишља дубље о ономе што је (можда) на тренутак бљеснуло у његовој свести. Он не промишља о сличностима између ислама и хришћанства - недуго након тога, хришћане ће поново видети као „đavole” (Апдајк 2006: 73).

С временом шеих Рашид постаје нестрпљивији и упорнији у својој индоктринацији:

Izgledalo je da je u poslednjevremevrlonervozan, kao da ga nešto pritiska; Ahmedu izgleda kao da je on fino izbrušeni 
element u nekoj strukturi, izložen prevelikom naprezanju. Ove nedelje imam se brzo razdražio kada su diskutovali o jednom stihu iz treće sure: Neka nikako ne misle nevernici da je dobro za njih što im dajemo dug život. Mi im ga dajemo samo zato da više ogreznu u grehu; njih čeka sramna patnja. Ahmed se usudio da pita učitelja da nema nečega sadističkog u izrugivanju, kao i mnogim sličnim stihovima. Usudio se da kaže: „Zar ne bi trebalo da cilj Božji bude, kao što je govorio Prorok, da se nevernici preobrate? U svakom slučaju, zar ne bi trebalo da im on pokaže milosrđe, a ne da se naslađuje njihovim bolom”.(Апдајк 2008: 84)

Ахмед се пита да ли је у складу са религијским погледом на свет наслађивати се туђом патњом, односно да ли је сходно свештеничком позиву да се имам срди и жели другоме зло. У овом сегменту јунак наликује на Стивена Дедалуса, главног јунака Џојсовог Портрета уметника у младости. Отац Арнал, предавач латинског, расрдиће се када „najbolji u razredu” не буде знао одговор на његово питање; наредиће му да клечи у средини разреда. Стивен Дедалус тада, слично Ахмеду, размишља о овом парадоксу: „Da li je to grehšto se otac Arnal razgnevio, ili je njemu dozvoljeno da se razgnevi kad su dečaci lenji zato što ih to tera da bolje uče, ili se samo pravi da je ljut? Sigurno zato što mu je to dozvoljeno, zato što sveštenik zna šta je greh i ne bi ga činio. Ali ako je on omaškom jedanput zgrešio, kako bi on otišao na ispovest?" (Џојс 2015: 48). Подсећамо да Стивен тада похађа језуитску школу у Клонгоусу, где, као одговор на репресију и дисциплину, долазе бројни несташлуци ученика, каткад врло озбиљни: у једном моменту дечаци краду вино које се користи за евхаристију.

Не можемо са сигурношћу тврдити да ли је сличност између ова два сегмента из Терористе и Портрета уметника у младости типолошка или се може говорити о утицају, при чему ваља имати у виду да је Џојс један од аутора који је у великој мери утицао на Апдајка. У основи и једног и другог одељка је топос критике свештенства. Стивен Дедалус се неће усудити да пита оца Арнала оно што га занима, због тога што је то у конкретном историјском тренутку, крајем деветнаестог века, у језуитској школи - незамисливо. Постоји, дакле, одређена детерминисаност која произилази из духа времена, из друштвено-историјских прилика у којим лик обитава. С друге стране, јунаку који живи на почетку двадесет и првог века, у другачијим културолошким 
околностима, дозвољено је да постави свом учитељу такво питање. У овоме налазимо потврду Бахтиновог становишта да сазревање протагонисте у образовном роману није приватна ствар: он „одраста заједно са светом” и тако „одражава у себи историјски развој самог света” (Бахтин 2013: 15). Ахмедовова еманципацијау односу на Џојсовог јунака у конкретној ситуацији није искључиво резултат његовог личног „развоја”, већ пре свега „развоја” (Западног) друштва и цивилизације. Приказивањем јунака који под утицајем имама помишља да се физички обрачуна са иноверницима, Апдајк, чини се, најпре поручује да је савремени Западни свет посрнуо.

Бахтин сматра да јунак образовног романа „више није унутар епохе, већ на размеђу двеју епоха; тај прелаз се одвија у њему и кроз њега" (Бахтин 2013: 16). Ђерђ Лукач чак каже да се у централног Bildungsromana,„најјасније испољава тоталитет свијета” (Лукач 1968: 101). Тако је Апдајков јунак приказан као репрезентативна фигура човека у Западном свету с почетка двадесет првог века. Џек Леви често говори о савременом друштву које је толерантно (нпр. Апдајк 2006: $46,319)$, односно да америчко друштво номинално инсистира на инклузивности, а, заправо, у пракси - где видимо да ученици исмевају Ахмеда јер је мислиман - ови се принципи изневеравају. Предочена недоследности још један је разлог јунакове фрустрације. И у њој се, дакле, може огледати „размеђа двеју епоха”, о којој говори Бахтин.

Шеих Рашид постаје све нестрпљивији, а његове дискретне алузије да се непријатељ треба уништити све транспарентније. У таквим тренуцима Ахмед ,želi da se čas završi” (Апдајк 2006: 116), jep ,se ne oseća potpuno prijatno sa svojim učiteljem ali ga, kao što Kuran i Hadit nalažu, poštuje" (Апдајк 2006: 110). Осамнаестогодишњи младић, који је каткад показивао ентузијазам поводом идеје да се непријатељ треба уништити - и у мислима у том смислу ишао даље од имама - када његов учитељ то отвореније предложи, он се колеба, јер, чини се, њему je, као младом, те стога не тако промишљеном човеку, била привлачна само апстрактна идеја о уништавању непријатеља. У интервјуу који је дао Чарлсу Мекгрету непосредно након објављивања Терористе, писац истиче како је хтео да проговори из перспективе терористе (Мекгрет 2006). Његов је терориста, дакле, неконзистентан,неодлучан, што би, према Едварду Саиду и његовој студији Оријентализам, била стереотипна представа о Оријенту (Саид 2008), премда, како смо већ 
ДА ЛИ ЈЕ АМЕРИКА КРМАЧА КОЈА ПРОЖДИРЕ СВОЈ ОКОТ ...

истакли, Ахмед не представља само Оријент. У складу са Ахмедом неодлучношћу - али не само са овом особином протагонисте - радни наслов романа био је Земља страха (према: Бечелор 2009: 86).Пишући о Вилхелму Мајстеру, Дилтај истиче да су у роману „ради контрастног појачања и допуне поред главне фигуре постављени други карактери" (Дилтај 2004: 175); што се најбоље може уочити у односу Ахмеда и шеиха Рашида. Исламски свештеник на више планова деградира лик протагонисте. Ипак, пошто је Терориста модеран роман, контраст међу ликовима није тако заоштрен, већ је умногоме нијансиранији.

На наговор свог учитеља јунак почиње да ради за „Ексленси”, фирму која тргује намештајем, а којој је, према шеиховим речима, „potrebanmlad vozač kamiona koji nema nečiste navike i koji je čvrst u našoj veri” (Апдајк 2008: 154). Притворни и злонамерни имам, који Ахмеда, заправо, посматра као Другост, биће тада поприлично задовољан:

Šeiha ovo zabavlja, jemenske ženski sive oči se skupljaju. Za njega je Ahmed Amerikanac. Nikakva revnost i izučavanje Kurana ne mogu promeniti rasu njegove majke niti očevo odsustvo. Nepostojanje očeva, neuspeh očeva da ljude uče odanosti domu, jedno je od obeležja ovog dekadentnog društva bez korena. Šeih Rašid - čovek malen i vitak kao bodež, sa opasnim lukavstvom u sebi, koji povremeno nagoveštava da Kuran možda nije oduvek unapred postojao u raju, kuda je Proroka odvelo jedno noćno putovanje na konju Buraku - ne nudi sebe za oca; u njegovom gledanju na Ahmeda ima nešto bratsko i cinično, trun neprijateljstva (Апдајк 2008: 157)

У образовном роману протагониста би требало да се афирмише и развије кроз акцију, искуство, односно делање у свету. У првом делу Терористе Ахмед се не шаље у живот, у стварна збивања, већ бива одвучен од њих: фокусира се на унутрашњи живот, на рефлексију, тако што чита и изучава Куран. У складу са тим, његова сазнања и закључци долазе управо из језика, из разговора - из наратива. У другом делу романа Ахмед би требало да потврди своју „веру” и у делатном смислу, тако што ће се жртвовати за ислам. Аристотеловски речено, vita contemplativa замениће vita activa. Ахмед почиње да превози намештај за Либанца Чарлија и његовог оца. Чарли се представља као распусан средовечни човек који понајчешће прича о женама и о по- 
литици. Његова функција у роману је да на конкретан начин Ахмеда припреми за жртвовање за ислам, да код њега, како је истакла Драгана Машовић, унесе политичке мотиве, као и да отклони евентуалне моралне и патриотско-емоционалне препреке (Машовић 2018: 153). На завршетку романа протагониста од Џека Левија сазнаје да је Чарли, заправо, Ција агент и да му је намера била да преко Ахмеда раскринка исламске фундаменталисте (Апдајк 2006: 307).

Социолог Фархад Косрокавар истиче како је у мотивисању нових кандидата за свету смрт важно осећање да је немогуће живети достојанствено у овом свету, којим доминирају снаге зла (према: Мићић 2006: 186). Док обавља свој посао, Апдајков јунак осећа се прочишћено, слободно и изоловано од спољашњег света, управо због тога што би камион требало да буде средство које ће га одвести у простор трансцеденције, а, самим тим, и чистоте: „Ahmed se oseća čistim u kamionu, odsečen od prostor sveta, njegovih ulica punih pseće prljavštine i komadića plastike i hartije koji lete; oseća da je čist i slobodan" (Апдајк 2006: 169). У том смислу нарочито га је оптерећивала сопствена сексуалност:

On bi još od detinjstva u svojim snovima ponekad leteo duž hodnika ili klizio trotoarima nekoliko stopa iznad zemlje, a ponekad bi se probudio sa erekcijom ili, što je još sramnije, s velikom mokrom flekom na unutrašnjoj strani šlica od pižame. Uzaludno je tražio seksualne savete od Kurana. On je govorio o nečistoći, ali samo u odnosu na žene, o njihovoj menstruaciji, dojenju odojčadi. Našao je misteriozne reči u drugoj suri: Žene su njive vaše, i vi njivama svojim prilazite kako hoćete, a pripremite što i za duše svoje. I bojte se Alaha i znajte da ćete pred Njega stati.U stihu pre toga pročitao je da su žene zagađenje.Zato ne općite sa ženama za vrijeem mesečnog pranja, i ne prilazite im dok se ne okupaju. A kada se okupaju, onda im prilazite onako kako vam je Alah naredio. Alah zaista voli one koji se često kaju i voli one koji se mnogo čiste. (Апдајк 2006: 169)

Најпре подсећамо да су откривање љубави и еротских доживљаја типични сегменти образовног романа. Овај и други слични делови Терористе указују на ограниченост рација, учења, образовног процеса (који је у делу иронизован), те и на дозу узалудности у оквиру „усавршавања” у верском животу: постоје универзалне људске осо- 
бине које се врло тешко могу еманциповати и уподобити одређеним правилима. Тако ће Ахмедова сексуалност на посредан начин утицати на његову одлуку да се жртвује за ислам: убиством које је уједно и самоубиство, према шеиховом учењу, јунак би отишао у рајске пределе и на тај начин би се заувек ослободио свог тела и телесности.

Када почне да ради за „Ексленси”, протагониста задобија извесну дозу самопоуздања, па и дрскости. Када му Чарли, који га зове Медмене, каже како треба да буде концетрисан док вози, Ахмед му пркосно и иронично одговара: „Stvarno?”, Ahmed pokušava da zadirkuje starijeg čoveka, njegovog libansko-američkog brata, da bi mu promenio namršteno ozbiljno raspoloženje. ,Zar ne bi trebalo da se automobili meni sklone sa puta?” (Апдајк 2006: 170). Млад човек који се, тиме што је почео да привређује, у одређеној мери осамосталио, може задобити, видимо, и дозу одважности и дрскости. То што Ахмед „zadirkuje” (Apdajk 2006: 170) Чарлија и себе види супериорног у односу на околину (,Zar ne bi trebalo da se automobili meni sklone sa puta?”), у вези је и са мотивом буба са почетка романа, односно са призором где јунак себе посматра као својеврсног бога у односу на инсекте. Он, чини се, и овде уображавабожје прерогативе.

У једном од разговора о политици који ће повести Ахмед, Чарли и његов отац, читамо: „Džihad ne mora da znači rat”, primećuje Ahmed dok mu je glas od stidljivosti promukao. „To znači stremiti božjim putem. Možda da znači 'unutrašnja borba'. Шта је ,унутрашња борба"” (у оригиналу ,inner struggle”(Апдајк 2006: 126))? Ове јунакове речи су двосмислене. Могу указивати на интериоризовану, душевну човекову борбу са грехом и са искушењима, што би било аутентично религијско тумачење. У полемици са шеихом Рашидом коју смо коментарисали Ахмед одбацује фигуративну интерпретацију Курана, док се овде, може бити, залаже за такав вид егзецезе 7 .,Унутрашња борба” може се пак поимати и као физичка, буквално схваћена, борба - у оквиру, унутар Америке (тзв. homegrown/domestic terrorism). Тако је ова синтагма потенцијално милитантна.

Чарли на имплицитан настоји да убрза јунакову иницијацију, његово интегрисање у свет одраслих мушкараца: „Moramotisrediti da nešto potucaš!” (Apdajk 2006: 190), jep није „,prirodnošto si još nevin”

7 У постколонијалном и у великој мери тенденциозном читању Терористе, Икбар Алосман указује и на Ахмедову недоследност (Алосман 2018). 
(Апдајк 2006: 245). Убрзо ће му уговорити састанак, иако ће Ахмед, на известан начин, заобићи „грех”. Може бити да на овај начин Чарли, који игра улогу вулгарног „шофера”,настоји да Ахмеда уподоби „себи”, како би се између њих развило дубље поверење: са становишта религијског погледа на свет, упрљан грехом, заблудео, јунак би се можда лакше одлучио да уради оно што ће се од њега тражити. Када уђе у просторију где је уговорен састанак, биће запрепашћен када угледа - Џолирин. Њих двоје ће време углавном провести разговарајући; Ахмед јој се поверава: „Ponekad čeznem da se pridružim Bogu, da mu olakšam usamljenost. Tekšto je izgovorio te reči on shvata da je to bogohuljenje: $u$ dvadeset devetoj suri stoji: Alahu nije potrebna pomoć njegovih stvorenja" (Apdajk 2006: 241). Јунак предосећа да ће се од њега захтевати да изврши терористички напад и, чини се, покушава на неки начин да увери себе да он то заиста жели да уради. Приликом наредног одласка у џамију, шеих га обавештава који је његов задатак; иако није сигуран у своју одлику, Ахмед пристаје.

Сада већ студент, Стивен Дедалус, полемишући са колегом Дејвином о апсурдности људске жртве зарад отаџбине, поентира: „Kad se duša jednog čoveka rodi u ovoj zemlji, na nju bacaju mreže da bi je zadržali da ne uzleti. Govoriš mi o nacionalnosti, jeziku, veri. Ja ću pokušati da u letu mimoiđem te mreže [...] Irska je stara krmača koja jede svoju decu"(Џојс 2015: 198). Као што је познато, Стивен ће на крају романа отићи из земље, у добровољно изгнанство. Да ли би се, у контексту тумачења Апдајковог Терористе, могло рећи за Америку да је како би рекао Киш у наслову своје приче - „крмача која прождире свој окот"? Апдајк тематизује управо овај проблем: Ахмед за себе каже да, „naravno”, „nijestranac”, да, заправо, „nikadanije bio u inostranstvu” (Апдајк 2006: 42), а камоли на Истоку. Он себе види као Американца, у чему се, између осталог, огледа његово „грађанско” схватање националног идентитета. Јунак је све време неодлучан између „етничког” и „грађанског” поимања идентитета.

Када одлучи да се жртвује за ислам, Ахмед почиње дубље да преиспитује своју веру: „Da li je njegova sopstvena vera, povremeno bi se zapitao, mladalačka taština, način da se razlikuje od svih onih osuđenih, Džolirin i Tilenola i ostalih izgubljenih, već mrtvih, u Centralnoj gimnaziji”(Apdajk 2006: 288-9). Он овде освешћује да се његов идентитет заснива пре свега на антагонизму између њега и околине. Дру- 
ДА ЛИ ЈЕ АМЕРИКА КРМАЧА КОЈА ПРОЖДИРЕ СВОЈ ОКОТ ...

гим речима, јунак се у роману не изграђује тако што се афирмишу његове специфичности, већ тако што се негира свет око њега. Он пре зна шта (номинално) није, него шта заиста јесте. Ахмед свој идентитет заснива на негацији Другости као такве, премда је у његовом опхођењу према околини, како смо већ сугерисали, тај антагонизам мање изражен него што са̂м јунак може да увиди.

Како би пронашао мотив за своје жртвовање за ислам, он изнова и изнова чита Куран:

Reči mu govore, ali nemaju dovoljno smisla. On proučava arapski na suprotnoj strani i shvata da nevernici - kako je to čudno da se oni, đavoli, čuju u Svetom Kuranu - sumnjaju u vaskrsnuće tela koje je Prorok propovedao. I sam Ahmed jedvamože da zamisli obnavljanje svog tela kada uspe da ga napusti; umesto toga on vidi svoj duh, tu malu stvar u njemu koja neprestano govori: 'Ja... ja...', i ulaziodmah u sledećiživot, kao da gurakrozobrtnavrata. (Апдајк 2006: 290)

Јунак овде сумња и у основне постулате ислама: ,jедва може да замисли" васкрсење свога тела; уместо тога, он види свој дух, „ту малу ствар” која понавља заменицу ,ја”. Дух се овде приказује као „мала”, егоистична „ствар”, чиме се сугерише да је код Ахмеда (погрешно схваћена) духовност поклекла пред жељом за овоземљским животом. Може бити и да протагониста на овом месту имплицира славу коју ће самоубиством достићи у исламском свету, како му је шеих обећао. Он размишља и о неверницима који сумњају у васкрсење. Овај сегмент се може посматрати и као метапоетички, јер са̂м Ахмед у Курану покушава да нађе оправдање за своје евентуално жртвовање за џихад и тако је управо он тај који сумња, у чему се, између осталог, огледа веома суптилна приповедачева иронија. Речи из Курана које говоре о сумњи у васкрсење могле би се односити и на Библију, где се у Јеванђељу по Матеји описује Христово васкрсење, те се каже и како „неки посумњаше” у њега (Библија 2012: 1239).

Дефиниција образовног романа коју нуди Карл фон Моргенштерн укључује и компонентну читалачке рецепције, посредством које се и реципијент књижевног текста - изграђује (Махони 1991: 100101). Сходно томе, промишљени казивач приче о Ахмеду настоји да образује читаоца: да подсети да се ислам и хришћанство заснивају на 
бројним заједничким постулатима, али и да сугерише да свете књиге нису потпуно оригинални нити аутономне творевине, већ су органски део културе у којој настају, због чега су често написани под утицајем других текстова. Јунака збуњује и то што се у Курану уопште помињу неверници, што им се придаје та врста значаја. Ова мисао такође може бити последица његове сумње у оправданост и утемељеност одлуке да се жртвује за џихад. Наиме, чини се да је овде имплицирано становиште да иноверници нису толико омражени у светој књизи колико Ахмед мисли да би требало да буду. Јунак овде као да преиспитује већ донету одлуку о терористичком нападу. Дубоко у себи, он увића аспурд евентуалног самоубиства.

Наредни сегменти романа представљају његову кулминациону тачку. Бројни детаљи који следе указују на Ахмедову несигурност. На пример, оног јутра када крене да реализује свој задатак, са носталгијом помишља на школу коју је похађао, а према којој је имао изразито негативан став: „Za Ahmeda neće više biti vraćanja u školu. Centralna gimnazija mu sada izgleda, sa svim svojim zastrašujućim žamorom i bezbožnim podrugivanjem, kao minijaturni zamak, kao igračka, bezazleno mesto bezbednosti i odloženog donošenja odluka" (Апдајк 2006: 294). УПлашен и већ помало сумњичав, док буде чекао Чарлија, размишљаће и о Џолирин: „Ahmedovo srce kuca kao one noći sa Džolirin. Sada mu je žao što je to propustio, što je nije iskoristio kada je za to bila plaćena" (Апдајк 2006: 296). Близина танатоса хипертрофира ерос, те Ахмед жали што је пропустио приликуда буде са девојком. Јунак ипак покушава да увери себе да „оno što on sada radi odigrava se u šaci Božje ruke, njegove velike, sveobuhvatne volje” (Апдајк 2006: 299), због чега „mora da sačuva prisebnost, tako što će zamisliti da je on božji instrument, hladan i čvrst i određen i nepromišljen, kakav treba da bude instrument" (Апдајк 2006: 302). За њега је, чини се, извршење самоубиства зарад џихада питање да ли он ваш или Наполеон. Даље, размишљање о убиству тј. самоубиству супротно је телеологији образовног романа, јер би оно поништило личност и обесмислило процес образовања, чији је циљ формирана личност. И у овом аспекту, дакле, Терориста деконструише Bildungsroman. По томе што своју субјективност поставља као закон, Ахмед наликује на штурмундраговског, Гетеовог Вертера.

Чарли се не појављује на договореном месту, па Ахмед одлучује да сам изврши свој задатак. Камион који му је за то додељен није онај 
који је возио у „Ексленсију”: „Ovimkamionom se upravljadrugačije od Ekslensija, koji se blago njihao, kao da vozač sedi na vratu slona. Kad vozi kamion sa natpisom 'Sistemi za postavljanje zastora na prozorima',on ne oseća nikakvu organsku simpatiju. Volan ne odgovara njegovim rukama" (Апдајк 2006: 303). Чини се да је у овом наводу фокализатор Ахмед: јунак субјективно види камион; наиме, волан, може бити, у потпуности одговара његовим рукама, али је његова перспектива, због колебања и несигурности, извитоперена.

Неки човек му тада маше. Убрзо схвата да је то Џек Леви, школски саветник. Помисливши да школски саветник има „poruku od Čarlija” (Апдајк 2006: 304) или „,nekuhitnuporukuodnjegovemajke” (Апдајк 2006: 305), Ахмед ће се колебати да ли да му допусти да уђе у камион. Пошто ће се на семафору убрзо бити црвено светло, принуђен је да стане, па Џек Леви куца на врата: „Zbunjen, naučen da ne pokazuje nepoštovanje prema profesoru, Ahmed pruža ruku i otključava vrata" (Апдајк 2006: 305). Нисмо сигурно да ли нам ово говори приповедач или пак јунак - као изговор за то што је пустио Џека Левија да уђе. Школски саветник је помоћу сестре своје супруге, која ради у служби безбедности од терористичких напада, дознао да Ахмед намерава да изврши самоубилачки терористички напад, због чега је похрлио да га пронађе и у томе спречи.

Протагониста тада Левија, човека који је био са његовом мајком, види као алтернативну очинску фигуру (Алгамди 2015: 6): „Postojao je otac koji je iščezao pre nego što je mogao da u pamćenje stavi njegovu sliku, a onda je Čarli bio prijateljski raspoložen prema njemu i pokazivao mu puteve, i sada je ovaj umorni Jevrejin koji kao da se oblačio u mraku zauzeo njihovo mesto, prazan prostor pored njega" (Апдајк 2006: 307). Алгамди сматра да ће Леви успети да одговори јунака од идеје да изврши напад управо због тога што је потенцијална фигура оца (Алгамди 2015: 6). Овом уверењу иде у прилог и то што школски саветник у тренутку када га Ахмед упозори да изађе из камиона јер ће активирати детонатор, Леви одговара: „Mislim da neću da izađem. Mi smo u ovome zajedno, sine” (Апдајк 2006: 314). Ни када сазна да је Чарли мртав, односно да је био тајни агент у настојању да раскринка друге, а не Ахмеда, јунак не одустаје од идеје да се жртвује за ислам, позивајући се да оне делове Курана где се говори како невернике треба „spaliti” и „zgaziti”, ,jer su zaboravili Boga” (Апдајк 2006: 312). Главни 
аргумент Џека Левија је да су сви који живе у Америци - Американции да због тога не треба да активира детонатор: „Ma, hajde, mi smo svi ovde Amerikanci. U tome i jeste stvar, zar ti to nisu rekli u Centralnoj gimnaziji? Amerikanac irskog porekla, Amerikanac afričkog porekla, Amerikanac jevrejskog porekla; ima čak i Amerikanaca arapskog porekla" (Апдајк 2006: 319), али дубљи разговор прекида улазак у тунел.

Ахмед ће тада у возилу исред угледати децу која покушавају да привуку његову пажњу. Драгана Машовић сматра да ће поглед на њих, потенцијалне жртве, утицати на јунакову одлуку да не изврши самоубилачки напад (Машовић 2018: 144). Поред тога што су потенцијалне жртве, она су и чист и неискварен облик егзистенције, којој он стреми. Због тога, између осталог, Ахмед одустаје од плана. У Курану је ваљаном муслуману обећан рај са десетинама девица; призор са децом, на вишеструко посредован начин, указује да рај као простор неискварености треба остварити и у оквиру овоземаљске егзистенције; симбол таквог живота јесу управо деца. Тада Ахмед „umirujuće diže prste desne ruke sa volana i maše im, kao što mlataraju noge bube koja leži na leđima. Konačno pozdravljeni, mališani se smeše i Ahmed ne može a da se i on ne nasmeši njima" (Ахмед 2006: 324). Јунак себе види као бубу ${ }^{8}$, и то у положају у ком је немоћна: када лежи на леђима, те може једино беспомоћно да „маше” ногама. У тренуцима док су му пред очима деца, јунак је, дакле, немоћан да убије.

Он ће се у последњем тренутку предомислити, најпре због тога што ће се сетити одељка из Курана где се каже да Бог „,ne želi da oskrnavimo Njegovu tvorevinu želeći smrt. On hoće život” (Апдајк 2006: 324). Значење ових речи слично је по(р)уци „Књиге пророка Јоне”, чији сегмент стоји у мотоу романа: „SadaGospode, uzmidušu moju od mene, / jer mi je bolje umrijeti nego živjeti. / A Gospod reče: je li dobro što se srdiš?" (Апдајк 2006: 5). Јона се срди зато што ће Бог помиловао Нинивљане. Тада му Бог на сликовит начин објашњава да је он није Бог само Израиљаца већ свих људи, те стога има милости и према припадницима других заједница. Ахмед је по свом антагонистичком односу према Другости сличан Јони. Тако и Јону и Ахмеда божја ин-

8

Било би интересантно и надасве плодоносно за разумевање Апдајковог романа у неком од наредних истраживања подробније испитати на који начин се инсекти приказују у Терористи, односно у Џојсовом Портрету уметника у младости. 
ДА ЛИ ЈЕ АМЕРИКА КРМАЧА КОЈА ПРОЖДИРЕ СВОЈ ОКОТ ...

станца „враћа” на људску меру. Тако и ови сегменти романа позивају на толеранцију и религијски релативизам.

Још један разлог зашто Ахмед неће притиснути детонатор је тај што се он гнуша органског отпада. Неколико дана пре него што крене да изврши свој задатак, посматра бубу и размишља: „Mnogi bi dečaciTilenol, na primer - jednostavno smrvili ovo iritirajuće prisustvo nogom, ali za Ahmeda takav izbor ne postoji: to bi imalo za rezultat spljeskan leš, zgnječeno zamršeno klupko maleckih delova i prosute tečnosti iz tela, i on ne želi da posmatra nikakav sličan organski užas" (Апдајк 2006: 269). Овај сегмент на известан начин антиципира Ахмедову мисао да Бог не жели „da oskrnavimo njegovu tvorevinu želeći smrt”.

Валтер Грунциг сматра да ликови у Терористи један другог хуманизују (према: Крибернег 2011: 219), што је према нашем уверењу само донекле тачно. Џолирин продуховљује Ахмеда, најпре тако што га позива на литургију, где јунак барем на тренутак (на посредан начин) освешћује апсурд идеје о уништењу иноверникаิ; оно што је много важније за формирање протагонисте, ова девојка у њему буди велике симпатије и осећања за која није знао ни да постоје. Џолирин га, заправо, у највећој мери епанципује: он се заљубљује у њу, иако она припада другој конфесионалној средини, односно иако њен поглед на свет уопште и није религијски! У том смислу Апдајк даје предност емотивном и ирационалном, науштрб оног образовања који се заснива на принципу рационалног. Пошто Ахмед не развија дубљи однос са мајком, не би се могло говорити како једно друго оплемењују. Занимљиво је што у роману не видимо Ахмедову реакцију на учитељеву издају; он не размишља о њој, већ само одлучује да изврши свој задатак, за који сматра да му је додељена од стране божје инстанце. Џек Леви, човек који у делу представља школу, тј. педагошку институцију, само ће донекле утицати на Ахмедову одлуку: када га Џек у једном моменту подржи у идеји да активира детонатор, јер је и са̂м незадовољан својим животом, Ахмед ће устукнути, зато што сматра да његов („чист”, џихадски) мотив за (само)убиство не сме да буде контаминиран разлозима неког другог. Протагониста ће, чини се, пре сâм, односно на основу сопствене перцепције, у последњем тренутку донети одлуку. Тако завршетак Терористе заобилази тему смрти, што је, према Лукачу, још један од поетичких одлика образовног романа (Лукач 1968: 106). 
У последњем параграфу романа фокализатор је Ахмед; у њему се открива да јунак није доживео истински духовни преображај, да није доживео епифанију. У реченици којом се дело затвара, као и у првој реченици Терористе, он Другост види као непријатељску:

Svuda oko njih, uz Osmu aveniju pa sve do Brodveja, velikim gradom mile ljudi, neki lepo obučeni, mnogi otrcani, jedan broj je lep, ali većina nije, svi zbog ogromnih građevina okolo izgledaju kao insekti, ali svi brzaju, žure, zaokupljeni na mlečnom jutarnjem suncu nekim planom ili zamisli ili nadom, kojih se čvrsto drže, njihovim razlogom za život za još jedan dan, dok je svaki od njih živ nabijen na čiodu savesti, usmeren na napredovanje i samoodržanje. To i samo to. Ovi đavoli su mi oduzeli mog Boga, misli Ahmed. (Апдајк 2006: 328)

Драгана Машовић сматра да је Ахмед свестан,,[...] дасуму 'ђаволи', ипак, 'одузелиБога', и дасевраћа у 'обичан' живот у комећеонсамморатидапреузместарање о свомживоту и, као и остали, о својим плановима, макар то значило и да ће са њима поделити празнину, таворење, и површносткултуре". (Машовић 2018: 155), те увиђа да га у животу чека само усмереност на напредовање и самоодржање (Машовић 2018: 155).

Ахмед се суштински не измирује са светом, односно не успева да достигне „извојевану и изборену зрелост”, о којој пише Лукач: „Садржај ове зрелости је идеал слободне људскости која схвата и прихвата све друштвене структуре живота као нужне форме људске заједнице" (Лукач 1968: 100). Јунак се не еманципује од антагонистичког погледа на Другост; њему је и даље иманентна екстремистичка исламска позиција. Као што смо показали, он нема храбрости да изврши терористички напад. Одвећ му је стало до овоземаљске егзистенције; уз то, Ахмед има одређену дозу емпатије према људима који га окружују, нарочито према онима који несвесно живе његов идеал, а то је идеал чистоте и неискварености. У складу са тим, помирење са светом овде је само наговештено. Писац пак завршетак романа оставља отвореним: нисмо сигурни да ли ће одустати од свог идеала или ће се истински помирити са својом околином. Кружна композција дела сугерише да Ахмед неће променити своју перцепцију. У складу са тим,јунак је и на крају деланеформиран.Комплексност централне фигуре у 
Терористипоказује даовим делом писац у одређеној мери успева да превреднује стереотипну представу о муслиманима, иако нијансиран и суптилан став о припадницима ове конфесије није очигледан, већ је „скривен” у дубинским слојевима текста. И да закључимо: анализирани аспекти романа сведоче о томе да је у савременој књижевности могућа једино деконструисана верзија образовног романа.

\section{ЛИТЕРАТУРА}

Алгамди 2015: A. Alghamdi, „Terrorism as a Gendered Familial Psychodrama in John Updike's Terrorist", Modernaspråk- Upsala: Institutionen förmodernaspråk, Uppsala University, Vol. 109, No 1 (2015), 1-12.

Алосман 2018: M.I. M.Alosman, „Differentiation and Imperfectionality in John Updike's Terrorist", The Southeast Asian Journal of English Language Studies, Vol. 24 (2), 58-70.

Бахтин 2013: М. Бахтин „Роман о васпитању и његов значај у историји реа-

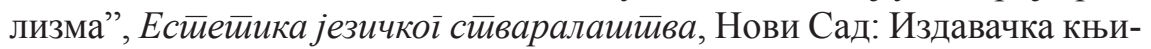
жарница Зорана Стојановића, стр. 5-65.

Бечелор 2009: В. Batchelor, Running Toward the Apocalipse: John Updike's New America: https://scholarcommons.usf.edu/cgi/viewcontent.cgi?articl $\mathrm{e}=2844 \&$ context $=$ etd\&fbclid=IwAR3wSW9vUzjciEI52WuuRenG8SP5zj xFxiCwhZXDevhzcBYu9Q_DZCGe31o, pristupljeno 4. 9. 2020.

Бодријар 2007: Ž. Bodrijar, Duh terorizma, sa francuskog preveo Dejan Ilić, Beograd: Arhipelag.

Дилтај 2004: V. Diltaj, Doživljaj i pesništvo, sa nemačkog preveo Saša Radojčić, Novi Sad: Orpheus.

Дојчиновић 2018: B. Dojčinović, „Zeka Angstrom (opet) beži”, pogovor u: Dž. Apdajk, Beži, zeko, beži , Beograd: Laguna, str. 355-380.

Дојчиновић Нешић 2007: В. Dojčinović Nešić, Kartograf modernog sveta: romani Džona Apdajka, Beograd: Filološki fakultet.

Јакобс, Краузе 2000: J. Jakobs, M. Krauze, „Nemački obrazovni roman. Istorija žanra od XVIII do XX veka", Reč: časopis za književnost i kulturu, sa nemačkog prevela Tijana Obradović, broj 60 (6), god. 2000, str. 379-398.

Лукач 1968: Đ. Lukač, „Godine učenja Vilhelma Majstera kao pokušaj sinteze",Teorija romana: jedan filozofsko historijski pokušaj o formama velike epske literature, Sarajevo: Izdavačko preduzeće „Veselin Masleša”, str. 99-108. 
Крибернег 2011: U. Kriebernegg, „'Hey, Come On, We'Re All Americans Here': The Representation of Muslim-American Identity in John Updike's Terrorist", Belgrade English Language and Literature Studies, Vol. 3 (2011), 215-228.

Мајлс 2000: D. H. Majls, „Pikarov put do ispovedaonice. Kako se menjao junak nemačkog obrazovnog romana", Reč: časopis za književnost $i$ kulturu, sa engleskog prevela Aleksandra Bajazetov-Vučen, broj 60 (6), god. 2000, str. 399-416.

Mate 2017: S. Mathé, „Imagining the Perpetrator: Reflections on the Terrorist as Other in Updike, DeLillo, and Amis", in: The John Updike Review, Cincinnati: University of Cincinnati, John Updike Society, volume 5, number 2,summer 2017, 13-30.

Махони 1991: D. F. Mahoney, „The Apprenticeship of the Reader: The Bildungsroman of the 'Age od Goethe", in: Reflection and Action: Essays on the Bildungsroman, edited by James Hardin, Chapel Hill: University of South Carolina Press, 97-117.

Мацено, Нортон 2017: L. W. Mazzeno, S. Norton, „Old World Readings of a New World Novel: European Perspectives on John Updike's Terrorist”, in: The John Updike Review, Cincinnati: University of Cincinnati, John Updike Society,volume 5, number 2,summer 2017, 1-12.

Машовић 2018: D. Mašović, „Proces radikalizacije ličnosti u pravcu oboženja ili razboženja samoubilačkog teroriste (istorija slučaja: Terorista Džona Apdajka)", Društvene i humanističke studije 1, 7 (2018), str. 141-158.

Мекгрег 2006: C. Mc Greth, „In Terorist A Cautious Novelist Takes On A New Fear", interview with John Updike, https://www.nytimes.com/2006/05/31/ books/31updi.html, приступљено 04.08.2020.

Мићић 2006: P. Mićić, Samoubilački terorizam, Beograd: Udruženje diplomaca Centra Džordž Maršal.

Морети 2000: F. Moreti, „Bildungsroman kao simbolička forma”, Reč: časopis za književnost $i$ kulturu, sa engleskog prevela Aleksandra Kostić, broj 60 (6), god. 2000, str. 417-452.

Саид 2008²: E. Said, Orijentelizam, sa engleskog prevela Drinka Gojković, Beograd: Biblioteka XX vek.

Сејмонс: J. L. Sammons, „The Bildungsroman for Nonspecialists: An Attempt at a Clarification", in: Reflection and Action: Essays on the Bildungsroman, edited by James Hardin, Chapel Hill: University of South Carolina Press, $26-45$.

Смит 2010²: A. D. Smit, Nacionalni identitet, preveo sa engleskog Slobodan Đorđević, Beograd: Biblioteka XX vek. 
Панчић 2008: T. Pančić, „Ahmed među đavolima”, Pepeo bez bašte, Novi Sad: DOO Dnevnik - novine i časopisi, str. 219-223.

Матовић 2006: V. Matović, Samoubilački terorizam: kako se postaje „,mučenik”, Beograd: Nacionalni komitet za borbu protiv terorizma.

Црнковић 2007: П. Црнковић, „Општеприхваћена 'знања' и кратка пометеност историјским тренутком: Подземље Дона ДеЛила и Апдајков Те-

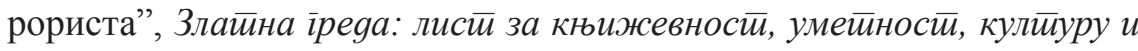
мишљење, год. 7, број 72/73, октобар-новембар 2007, стр. 48-54.

Хегел 1961: Г. В. Ф. Хегел, Естеиеиика III, са немачког превео др Никола Поповић, Београд: Култура.

\section{ИЗВОРИ}

Апдајк 2006: Dž. Apdajk, Terorista, sa engleskog prevela Dušanka Vujić, Beograd: Izdavačko preduzeće „Filip Višnjić”.

Апдајк 20072: J. Updike, Terrorist, New York: Ballantine Books.

Апдајк 2003: J. Updike, The Early Stories: 1953-1975, New York: A. A. Knopf. Џojc 2015: Dž. Džojs, Portret umetnika u mladosti, sa engleskog preveo Petar Ćurčija, Beograd: Lom.

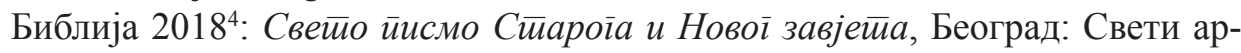
хијерејски синод Српске православне цркве.

Ман 2017: T. Man, Čarobni breg I-II, prvi tom sa nemačkog jezika preveo dr Miloš Đorđević, drugi Nikola Polovina, Beograd-Podgorica: Nova knjiga. 


\title{
Magda Milikić
}

\section{IS AMERICA A SOW THAT EATS HER FARROW: JOHN UPDIKE'S TERRORIST AS A BILDUNGSROMAN}

\begin{abstract}
Summary
In the paper we analysed $22^{\text {nd }}$ John Updike's novel, Terrorist, to ascertain whether this novel could be viewed as a Bildungsroman. In accordance with this, we emphasized those aspects that agree with the poetics of this literary genre. Our investigation is based on theoretical insights that Hegel, Lukács and Bakhtin offered on this literary genre; furthermore, we also relied on some contemporary theories regarding this issue. One of the main features of Bildungsroman is the change that a young man goes through; this change has a crucial role in shaping his personality and arises on the basis of a dialectical relationship between the self and the environment. Theorists argue that this conflict is successfully resolved in Bilgungsroman. By analysing characters and relations among them, narrative layers of the text and intertextual dialogue in Updike's Terrorist, we strove to point out how Updike deconstructs this literary genre by showing a young man, Ahmad, who - under the influence of an imam - considers and plans to became a suicide bomber. Also, we indicated how the author's approach to this sensitive topic is a nuanced one: the novel is militant only on its surface.
\end{abstract}

Key words: John Updike, Terrorist, Bildungsroman, Islamic fundamentalism, Ahmad Ashmawi Mulloy, character development, epiphany 